KAWISTARA

VOLUME 6

No. 1, 21 April 2016

Halaman 1-112

\title{
PERKIRAAN POLA MIGRASI ANTAR PROVINSI DI INDONESIA: PENDEKATAN DEMOGRAFI-EKONOMI
}

\author{
Albertus Girik Allo \\ Fakultas Ekonomi Universitas Negeri Papua \\ Email: albertusgirikallo@yahoo.co.id
}

\begin{abstract}
The difference in the level of welfare among regions was an impeller factor for people to migrate. Data from the Population Census in 2010 showed that the province's largest destination of migrants were West Java, DKI Jakarta and Banten. The purposes of this study is to observe how many the migrate response due to the differences in the level of welfare among the provinces in Indonesia, and to calculate the probability of migration for each province. The research method used in this study is Demographic-Economic Approach (Issermen et al, 1985), and then modified with using limited data in Indonesia. Economic variables used in this study are Ratio of Minimum Provincial Wage/ Decent Living Needs (UMP/KHL), Gini Index, and Gross Regional Domestic Product (PDRB) per capita. The results show that economic attractiveness value for variable of UMP/KHL ratio which is 0.2501 (significant), variable of Gini index is -0.0730 (insignificant), and PDRB per capita is 0.2742 (significant). The tendency of migrations among the provinces in Indonesia is still dominated by the migrants from Java and Bali Islands. The other result shows that people in DI Yogyakarta Province have a tendency not to perform migration.
\end{abstract}

Keywords: Migration; Demographic-Economic approach; Economic attractiveness; Tendency of migration

\begin{abstract}
ABSTRAK
Perbedaan tingkat kesejahteraan antar wilayah merupakan faktor pendorong bagi seseorang melakukan migrasi. Data hasil Sensus Penduduk (SP) tahun 2010 menunjukkan bahwa provinsi tujuan terbesar dari para migran adalah Jawa Barat, DKI Jakarta, dan Banten. Tujuan dari penelitian ini adalah untuk melihat berapa besar respon migrasi akibat perbedaan tingkat kesejahteraan antar provinsi di Indonesia, serta menghitung peluang migrasi pada masing-masing provinsi. Metode penelitian yang digunakan dalam penelitian ini adalah pendekatan model demografi-ekonomi (Issermen et al, 1985) yang kemudian dimodifikasi dengan menggunakan data yang terbatas di Indonesia. Variabel ekonomi yang digunakan adalah Rasio Upah Minimum Provinsi/Kebutuhan Hidup Layak (UMP/KHL), Indeks Gini, Produk Domestik Regional Bruto (PDRB) per kapita. Hasil dari penelitian ini menunjukkan nilai economic attractiveness untuk variabel Rasio UMP/KHL sebesar 0,2501 (signifikan), variabel Indeks Gini -0,0730 (tidak signifikan), serta PDRB per kapita 0,2742 (signifikan). Kecenderungan migrasi antar provinsi di Indonesia masih didominasi oleh migrasi ke pulau Jawa dan Bali. Hasil lainnya menunjukkan bahwa masyarakat di Provinsi DI Yogyakarta memiliki kecenderungan untuk tidak melakukan migrasi.
\end{abstract}

Kata Kunci: Migrasi; Pendekatan demografi-ekonomi; Economic attractiveness; Kecenderungan migrasi 


\section{PENGANTAR}

Migrasi merupakan persoalan yang mulai mendapatkan perhatian secara intensif sejak dimulainya era globalisasi. Perpindahan penduduk atau sering disebut dengan migrasi dapat dilakukan secara sukarela maupun tidak sukarela. Migrasi merupakan suatu tindakan yang diambil oleh seseorang sebagai reaksi atau respon terhadap perubahan sosial dan ekonomi (Tirtosudarmo, 2009). Perpindahan penduduk antara-wilayah baik pada tingkat kampung, distrik, kabupaten, provinsi dan negara disebabkan oleh berbagai macam alasan. Teori ekonomi menyebutkan bahwa arus migrasi antar wilayah lebih banyak disebabkan oleh adanya perbedaan upah tenaga kerja antara daerah asal dan daerah tujuan (Kerr dan Kerr, 2011). Perpindahan ini akan memberikan dampak terhadap tingkat kesejateraan, pendidikan, dan kesehatan dari para migran (Vujicic et al., 2004; Purnomo, 2009; Lu, 2010; Saptanto et al., 2011). Transfer penghasilan (remittance) terhadap keluarga di daerah asal merupakan salah satu dampak ekonomi yang diterima oleh keluarga dan daerah pengirim migran (Adams dan Page, 2005; Primawati, 2011).

Secara umum, keputusan orang melakukan migrasi adalah untuk memperoleh pekerjaan dan pendapatan yang lebih baik dibandingkan di daerah asal mereka (Heitmueller, 2005; Martin dan Zurcher, 2008; Purnomo, 2009; Mayda, 2010). Penambahan jumlah migran akan memberikan dampak positif dan negatif bagi masyarakat lokal dan wilayah tujuan migrasi. Jumlah migrasi yang semakin tinggi di suatu wilayah akan menyebabkan tingkat persaingan antar penduduk semakin tinggi. Selain itu, redistribusi pendapatan dan kebijakan kesejahteraan yang cenderung memihak kepada para migran karena mereka lebih banyak yang menganggur dan memiliki tingkat kesejahteraan yang lebih rendah dibandingkan dengan masyarakat lokal (Lumpe, 2007; Adema dan Ladaique, 2009; Giulietti et al., 2013). Sedangkan dampak positif dari adanya migrasi adalah pertumbuhan ekonomi yang semakin baik di daerah tujuan, di mana tingkat persaingan akan meningkatkan produktivitas tenaga kerja (The Word Bank, 2009; Devlin et al., 2014).

Migrasi dapat dikelompokkan dalam dua kategori, yaitu migrasi internasional dan migrasi internal. Deshingkar (2006) mengungkapkan bahwa migrasi internal lebih berpotensi untuk mengurangi kemiskinan dibandingkan dengan migrasi internasional karena pertama, migrasi internal akan menyebabkan pemerataan pendapatan karena adanya remittance yang lebih luas dibandingkan dengan migrasi internasional. Kedua, kemungkin peningkatan migrasi internal yang lebih cepat dibandingkan dengan migrasi internasional. Ketiga, migrasi internal didominasi oleh masyarakat miskin, sehingga mereka dapat keluar dari kemiskinan, sedangkan migrasi internasional didominasi oleh masyarakat menengah. Keempat, bertambahnya tenaga kerja akan mendorong pertumbuhan yang cepat pada sektor manufaktur, konstruksi, pertanian, ekonomi pesisir, dan jasa.

Migrasi tenaga kerja di Indonesia dilakukan dengan dua cara, yaitu migrasi internasional/migrasi ke luar negeri dan migrasi internal/migrasi dalam negeri. Migrasi internasional dilakukan atas dasar kesenjangan upah, di mana upah di luar negeri lebih besar dibandingkan dengan upah di Indonesia. Negara tujuan utama dari tenaga kerja Indoensia adalah Arab Saudi, Malaysia, Taiwan (RRC), Singapura, Hong Kong, Emirat Arab, dan negara-negara lainnya yang memiliki tingkat upah lebih tinggi (Badan Nasional Penempatan dan Perlindungan TKI di Luar Negeri/ BNP2TKI, 2013).

Dalam kurun waktu 30 tahun terakhir, migrasi internal menunjukkan peningkatan yang cepat terutama migran perempuan. Para migran cenderung untuk meninggalkan keluarga mereka di daerah asalnya dan melakukan migrasi untuk periode 2 (dua) minggu hingga 2 (dua) tahun (Deshingkar, 2006). Hasil Sensus Penduduk 2000, Sensus 
Penduduk Antar-Sensus 2005, dan Sensus Penduduk 2010 menunjukkan bahwa migrasi internal cenderung menuju ke kota-kota besar di Pulau Jawa dengan alasan utama adalah untuk mencari pekerjaan dan memperoleh upah yang lebih baik. Pada tahun 2010, migrasi keluar dari Pulau Sumatera sebanyak 0,3 juta migran dan sebagian besar $(87,67$ persen) menuju Pulau Jawa, dari Pulau Kalimantan sebesar 62,46 persen dari 0,1 juta migran, dari Pulau Sulawesi sebesar 20,76 persen dari 0,1 juta imigran dan dari pulau lainnya sebesar 48,74 persen dari 0,1 juta migran (Wahyuni dan Nuraini, 2013). Faktor yang diduga mempengaruhi arus migrasi ke Pulau Jawa antara lain adalah Pulau Jawa merupakan pusat pemerintahan dan merupakan pusat kegiatan ekonomi dan industri, sehingga banyak tersedia lapangan kerja serta kelengkapan fasilitas publik (pendidikan, kesehatan, komunikasi, dan lainnya). Kondisi ini memperlihatkan bahwa pola migrasi di Indonesia merupakan suatu reaksi atas kesempatan untuk memperoleh kehidupan yang lebih baik pada suatu wilayah tujuan.

Penelitian ini terkait dengan modifikasi model gravitasi tentang migrasi yang dikembangkan oleh Issermen, dkk (1985). Modifikasi model tersebut dengan memasukkan aspek demografi dan aspek ekonomi ke dalam model. Hasil penelitian Issermen et al (1985) menunjukkan bahwa pendekatan demografi-ekonomi memiliki tingkat kesalahan peramalan 20 persen lebih rendah dari model lainnya yang digunakan untuk memprediksi migrasi.

Model ini telah digunakan sebelumnya oleh Darmawan dan Chotib (2007) dengan menggunakan indeks ketertarikan ekonomi yang diwakili oleh Produk Domestik Regional Bruto (PDRB) per kapita, Upah Minimum Provinsi (UMP) dan Angka Pengangguran untuk memprediksi pola migrasi di Indonesia. Data yang digunakan adalah tahun 1995 dan tahun 2000 untuk setiap indeks ketertarikan ekonomi dan data migrasi menggunakan data tahun 2000 dan 2005. Adanya krisis ekonomi tahun 1998 menyebabkan pola migrasi antar provinsi di Indonesia pada periode sebelum dan sesudah krisis memiliki perbedaan. Penggabungan kedua periode tersebut akan menyebabkan bias dalam estimasi jika tidak melakukan penyesuaian terhadap indeksindeks ketertarikan ekonomi. Selain itu, pola migrasi sebelum krisis didominasi oleh migrasi yang disebabkan oleh adanya program transmigrasi.

Tujuan dari penelitian ini adalah untuk menganalisis seberapa besar respon migrasi akibat perbedaan tingkat kesejahteraan antarprovinsi di Indonesia, serta menghitung kemungkinan migrasi pada masing-masing provinsi. Dengan demikian, dapat diketahui provinsi mana yang dominan dalam menerima migran.

\section{Jenis dan Sumber Data}

Data yang digunakan dalam penelitian ini adalah data sekunder yang terdiri dari data migrasi dan data kesejahteraan (Rasio Kebutuhan Hidup Layak/KHL dan Upah Minimum Provinsi/UMP, indeks Gini, serta PDRB per kapita). Data migrasi yang digunakan adalah data migrasi hasil Sensus Penduduk 2000, Sensus Penduduk Antar Sensus 2005, dan Sensus Penduduk 2010. Sedangkan data aspek kesejahteraan menggunakan data tahun 2000 dan 2005 yang bersumber dari data makro yang diterbitkan oleh BPS dan lembaga lainnya yang berkompeten.

\section{Teknik Analisis Data}

Model yang digunakan untuk menganalisis data adalah model yang dikembangkan oleh Issermen et al tahun 1985, dengan memasukkan faktor ekonomi sebagai faktor penarik seseorang melakukan migrasi economic attractiveness. Model dasar dari pendekatan demografi adalah sebagai berikut:

$$
M_{i j}(t)=P_{i}(t-1)\left[\frac{M_{i j}(b)}{P_{i}(b-1)}\right]
$$


Persamaan (1) kemudian dimodifikasi dengan memasukkan unsur daya tarik ekonomi (economic attractiveness) dalam mengubah probabilitas seseorang melakukan migrasi. Hal ini disebabkan oleh dua indikator, pertama, migrasi tidak hanya ditentukan oleh aspek demografi, tetapi juga oleh aspek non-demografi (ekonomi dan politik). Kedua, hasil dari berbagai riset menunjukkan bahwa migrasi lebih banyak disebabkan oleh aspek ekonomi. Dengan demikian, diperoleh persamaan sebagai berikut:

$$
M_{i j}(t)=P_{i}(t-1)\left[\frac{M_{i j}(b)}{P_{i}(b-1)}\right]\left[\frac{A_{j}(t-1) / A_{n}(t-1)}{A_{j}(b-1) / A_{n}(b-1)}\right]^{r}
$$

Di mana,

$M_{i j} \quad=$ Migrasi dari wilayah $\mathrm{i}$ ke wilayah $\mathrm{j}$

$P_{i}^{i j} \quad=$ Penduduk wilayah $\mathrm{i}$

$A_{j} \quad=$ Indikator ekonomi wilayah $\mathrm{j}$

$A_{n} \quad=$ Indikator ekonomi secara nasional

$t \quad=$ periode migrasi

$b \quad=$ periode dasar migrasi

$r \quad=$ economic attractiveness

Issermen et al (1985) menggunakan data cross-section dari laporan tahunan untuk memprediksi pola migrasi. Dikarenakan keterbatasan data yang ada di Indonesia, di mana data migrasi hanya tersedia secara periodik (5 tahunan), maka dalam penelitian ini, model diatas kemudian dimodifikasi sebagai berikut:

$$
M_{i j}(2010)=P_{i}(2005)\left[\frac{M_{i j}(2005)}{P_{i}(2000)}\right]\left[\frac{A_{j}(2005) / A_{n}(2005)}{A_{j}(2000) / A_{n}(2000)}\right]^{\prime}
$$

Di mana,

$$
\begin{aligned}
M_{i j}(2010)= & \text { Migrasi dari wilayah i ke } \\
& \text { wilayah } \mathrm{j} \text { tahun } 2010 \\
M_{i j}(2005)= & \text { Migrasi dari wilayah i ke } \\
& \text { wilayah } \mathrm{j} \text { tahun } 2005 \\
P_{i}(2005)= & \text { Penduduk wilayah i tahun } 2005 \\
P_{i}(2000)= & \text { Penduduk wilayah i tahun } 2000 \\
A_{j}(2005)= & \text { Nilai Aspek Kesejahteraan } \\
& \text { wilayah j tahun 2005 } \\
A_{j}(2000)= & \text { Nilai Aspek Kesejahteraan } \\
& \text { wilayah j tahun 2000 } \\
A_{n}(2005)= & \text { Nilai Aspek Kesejahteraan } \\
& \text { nasional tahun 2005 } \\
A_{n}(2000)= & \text { Nilai Aspek Kesejahteraan }
\end{aligned}
$$

$$
\begin{array}{ll} 
& \text { nasional tahun } 2000 \\
i, j & = \\
\gamma & =\text { Provinsi di Indonesia }(1,2, \ldots, 25) \\
& \text { economic attractiveness }
\end{array}
$$

Provinsi yang ada di Indonesia saat ini berjumlah 34 provinsi, tetapi hanya 25 provinsi yang memiliki data migrasi tahun 2000, 2005, dan 2010. Provinsi pemekaran (Provinsi Bangka Belitung, Kepulauan Riau, Banten, Gorontalo, Sulawesi Barat, Maluku Utara, dan Papua Barat) tidak dimasukkan dalam penelitian karena pada tahun 2000 provinsi-provinsi tersebut masih tergabung dalam kabupaten induk. Sedangkan untuk Provinsi Aceh, tidak dimasukkan, karena tidak memiliki data migrasi pada tahun 2005 pada saat dilakukan Sensus Penduduk Antar Sensus tahun 2005 yang disebabkan oleh adanya bencana alam (tsunami). Untuk mendapatkan estimasi nilai "economic attractiveness" maka persamaan (3) diubah sebagai berikut:

$$
\begin{aligned}
& \ln M_{i j}(2010)=\ln P_{i}(2005)+\ln \left[\frac{M_{i j}(2005)}{P_{i}(2000)}\right]+ \\
& \gamma \ln \left[\frac{A_{j}(2005) / A_{n}(2005)}{A_{j}(2000) / A_{n}(2000)}\right] \\
& \ln M_{i j}(2010)=\ln P_{i}(2005)+\log \left[\frac{M_{i j}(2005)}{P_{i}(2000)}\right]= \\
& \gamma \ln \left[\frac{A_{j}(2005) / A_{n}(2005)}{A_{j}(2000) / A_{n}(2000)}\right]
\end{aligned}
$$

Kemudian, melihat kecenderungan orang yang melakukan migrasi karena aspek kesejahteraan, maka dilakukan hal sebagai berikut: pertama, membagi ruas kiri persamaan (3) dengan jumlah penduduk tahun sebelumnya, sehingga diperoleh matriks peluang seseorang melakukan migrasi dari provinsi i ke provinsi $\mathrm{j}$.

$$
\left[\frac{M_{i j}(2005)}{P_{i}(2000)}\right]=\Pi_{\mathrm{ij}}
$$

Kedua, membagi ruas kanan persamaan (3) dengan kemungkinan pertambahan penduduk akibat adanya migrasi karena aspek kesejahteraan, maka diperoleh matriks peluang seseorang melakukan migrasi akibat adanya pengaruh karena aspek kesejahteraan. 
Model tersebut disederhanakan sebagai berikut (Issermen et al., 1985).

$$
\frac{P_{i}(2005)\left[\frac{M_{i j}(2005)}{P_{i}(2000)}\right]\left[\frac{A_{j}(2005) / A_{n}(2005)}{A_{j}(2000) / A_{n}(2000)}\right]^{\gamma}}{\sum_{\mathrm{k}} \mathrm{M}_{\mathrm{ik}}(2005)\left[\frac{A_{k}(2005)}{A_{k}(2000)}\right]^{\gamma}}=\Pi \mathrm{E}_{\mathrm{ij}}
$$

$$
\frac{M_{i j}(2005)\left[\frac{A_{j}(2005)}{A_{j}(2000)}\right]^{\gamma}}{\sum_{\mathrm{k}} \mathrm{M}_{\mathrm{ik}}(2005)\left[\frac{A_{k}(2005)}{A_{k}(2000)}\right]^{\gamma}}=\Pi \mathrm{E}_{\mathrm{ij}}
$$

Di mana, (k) adalah provinsi tujuan lengkap dengan penduduk yang bertahan.

Ketiga, mengurangkan nilai peluang seseorang melakukan migrasi akibat adanya pengaruh karena aspek kesejahteraan (persamaan 6b) dengan nilai peluang seseorang melakukan migrasi dari provinsi (i) ke provinsi (j) (persamaan 5) akan menghasilkan kecenderungan seseorang melakukan migrasi karena adanya aspek kesejahteraan di daerah tujuan.

\section{PEMBAHASAN \\ Kondisi Migrasi}

Arus migrasi antar-pulau di Indonesia dipengaruhi oleh perbedaan jarak antar pulau-pulau tersebut. Semakin dekat jarak antar pulau, maka peluang seseorang melakukan migrasi lebih besar dibandingkan dengan pulau yang jauh. Data Sensus Penduduk tahun 2010 menunjukkan bahwa arus migrasi antar pulau yang paling banyak adalah antara pulau Sumatera dan Pulau Jawa. Jumlah migrasi di pulau Sumatera yang berasal dari pulau Jawa sebesar 91,33 persen, sedangkan jumlah migran dari pulau Sumatera ke pulau Jawa sebesar 61,85 persen dari total migran yang ada di Pulau Jawa (Handiyatmo, 2011).

Data hasil Sensus Penduduk tahun 2010 menunjukkan bahwa provinsi-provinsi di Pulau Jawa, baik sebagai provinsi pengirim/ asal (keluar), maupun provinsi penerima/ tujuan (masuk) masih mendominasi arus migrasi hingga tahun 2010. Provinsi ter- banyak yang menerima migran adalah Jawa Barat, sebesar lebih dari satu juta dengan distribusi 44,29 persen dari DKI Jakarta, 24,74 persen dari Jawa Tengah, dan 30,97 persen berasal dari provinsi lainnya. Sedangkan untuk arus migrasi keluar, Jawa Tengah merupakan provinsi yang paling besar yaitu 0,9 juta migran dengan distribusi 26 persen menuju Jawa Barat, 22,01 persen menuju DKI Jakarta, 9.46 persen menuju Banten, dan sisanya 42,53 persen menuju provinsi lain di Indonesia.

Kajian ini menggunakan data migrasi risen, karena migrasi ini lebih mencerminkan keadaan perpindahan penduduk terkini (keadaan lima tahun yang lalu). Hasil Sensus Penduduk tahun 2010 menunjukkan bahwa provinsi tujuan terbesar dari para migran adalah Jawa Barat (19,7 persen), DKI Jakarta (12,1 persen), dan Banten (8,8 persen). Sedangkan provinsi pengirim migran terbesar didominasi oleh Provinsi Jawa Tengah (18,7 persen), DKI Jakarta (16,9 persen), dan Jawa Barat (11,4 persen). Hal ini menunjukkan bahwa Pulau Jawa merupakan wilayah dengan mobilitas penduduk paling tinggi di Indonesia. Akan tetapi, jika dibandingkan dengan jumlah penduduk, Kepulauan Riau merupakan provinsi dengan komposisi penerima migran risen terbesar diikuti oleh DKI Jakarta dan DI Yogyakarta.

Karakteristik migrasi risen dapat dilihat dari beberapa aspek yaitu tempat tinggal, umur dan jenis kelamin, pendidikan, dan pekerjaan. Berdasarkan tempat tinggal, karakteristik ini dapat dibedakan menjadi daerah perkotaan dan daerah perdesaan. Jumlah migran yang tinggal di daerah perkotaan sebesar 4,0 juta migran dan di daerah perdesaan sebesar 1,4 juta migran. Jika dilihat dari umur migran, maka kelompok umur 20-24 tahun merupakan kelompok umur yang melakukan migran terbesar, sedangkan yang terendah yaitu kelompok umur 35-39 tahun. Kemudian, apabila dilihat dari aspek jenis kelamin, maka secara umum migran laki-laki lebih banyak dari migran perempuan, kecuali pada kelompok umur 15-19 tahun dan 65 
tahun ke atas. Karakteristik migran menurut pendidikan menunjukkan bahwa 36,55 persen migran berpendidikan minimal tamat SLTA/MA, 20,32 persen SLTP/MTs, 17,62 persen SD/MI, 13,68 persen Tidak/Belum Tamat SD, 7,93 persen S1/S2/S3, dan 3,90 persen D1/DII/DIII. Jika ditinjau dari aspek pekerjaan, maka 66,48 persen migran telah memiliki pekerjaan, di mana 59,06 persen bekerja pada sektor jasa, 25,07 persen sektor industi, dan 15,87 persen sektor pertanian. Berdasarkan status pekerjaan, maka sebagian besar migran $(65,23$ persen) bekerja sebagai buruh/karyawan/pegawai.

Tabel 1

Persentase Migrasi Risen (Migrasi Masuk dan Migrasi Keluar) berdasarkan Pulau di Indonesia Tahun 1980, 1985, 1990, 2000, 2005 dan 2010

\begin{tabular}{lccccccc}
\hline \multicolumn{1}{c}{ Kategori Pulau } & $\mathbf{1 9 8 0}$ & $\mathbf{1 9 8 5}$ & $\mathbf{1 9 9 0}$ & $\mathbf{1 9 9 5}$ & $\mathbf{2 0 0 0}$ & $\mathbf{2 0 0 5}$ & $\mathbf{2 0 1 0}$ \\
\hline Pulau Sumatera & & & & & & & \\
Migrasi Masuk & 33.34 & 20.98 & 22.63 & 18.47 & 24.14 & 21.71 & 23.20 \\
Migrasi Keluar & 18.05 & 21.87 & 19.82 & 23.10 & 24.22 & 19.91 & 21.46 \\
$\begin{array}{l}\text { Pulau Jawa } \\
\text { Migrasi Masuk }\end{array}$ & 48.44 & 61.00 & 58.54 & 62.92 & 56.15 & 59.65 & 54.29 \\
Migrasi Keluar & 67.53 & 64.68 & 66.35 & 60.79 & 60.91 & 63.44 & 62.72 \\
Bali dan Kepulauan Nusa Tenggara & & & & & & & \\
Migrasi Masuk & 2.40 & 2.53 & 2.50 & 3.23 & 3.86 & 3.45 & 3.70 \\
Migrasi Keluar & 3.54 & 2.41 & 2.69 & 2.97 & 2.77 & 2.68 & 2.86 \\
Pulau Kalimantan & & & & & & & \\
Migrasi Masuk & 7.07 & 6.93 & 7.95 & 6.82 & 7.44 & 6.56 & 8.94 \\
Migrasi Keluar & 3.11 & 4.25 & 4.39 & 5.04 & 3.19 & 4.47 & 3.92 \\
$\begin{array}{l}\text { Pulau Sulawesi } \\
\text { Migrasi Masuk }\end{array}$ & & & & & & & \\
Migrasi Keluar & 6.59 & 5.79 & 5.65 & 6.77 & 6.47 & 6.74 & 6.65 \\
Pulau Maluku dan Papua & 6.55 & 5.22 & 5.38 & 6.36 & 5.96 & 7.28 & 7.12 \\
Migrasi Masuk & & & & & & & \\
Migrasi Keluar & 2.16 & 2.76 & 2.73 & 1.80 & 1.94 & 1.89 & 3.23 \\
\hline
\end{tabular}

Sumber: BPS, 2014 (diolah)

\section{Kondisi Kesejahteraan}

Salah satu aspek yang mendorong orang melakukan migrasi adalah perbedaan kesejahteraan, kondisi ekonomi makro, geografi, budaya, dan demografi antara daerah asal dan daerah tujuan, di mana para migran berusaha untuk mencari selisih dari dari perbedaan tersebut (Mayda, 2010). Aspek kesejahteraan yang akan digunakan dalam penelitian ini meliputi rasio Upah Minimum Provinsi/ UMP per Kebutuhan Hidup Layak/KHL, Indeks Gini, dan PDRB per Kapita.

Upah Minimum Provinsi (UMP) merupakan salah satu pendekatan yang dapat digunakan untuk melihat pendapatan dari para migran. UMP sebagai faktor penarik memiliki hubungan positif maupun negatif terhadap migrasi. Hasil kajian dari Darma- wan dan Chotib (2007), UMP menunujukkan hasil negatif karena migran justru cenderung menuju daerah yang memiliki nilai UMP yang lebih rendah dibandingkan provinsi asalnya. Hasil sebaliknya ditunjukkan oleh kajian Wajdi (2010) dan Giulietti (2014) yang menunjukkan bahwa salah satu faktor penarik orang melakukan migrasi adalah faktor upah minimum, di mana kebijakan kenaikan upah minimum akan meningkatkan migrasi.

Permenakertrans No. 01 Tahun 1999 tentang Upah Minimum junto Kepmenakertrans No. 226/MEN/2000 tentang Perubahan Beberapa Pasal dalam Permenakertrans No. 01 Tahun 1999 menjelaskan bahwa upah minimum adalah upah bulanan terendah yang terdiri dari upah pokok termasuk tunjangan tetap, ber- 
laku bagi perkerja yang mempunyai masa kerja kurang dari 1 (satu) tahun. Salah satu pertimbangan dalam penetapan upah minimum adalah Kebutuhan Hidup Layak (KHL) yang diatur dalam Permenaker No. Per-17/Men/2005 tentang komponen dan pentahapan kebutuhan hidup layak.

Rasio antara UMP terhadap Kebutuhan Hidup Layak menunjukkan bahwa masih ada provinsi di Indonesia yang memiliki UMP lebih rendah dari kebutuhan hidup layak. Jika kita mengacu kepada Peraturan Menteri Tenaga Kerja dan Transmigrasi No.7 Tahun 2013 tentang Upah Minimum terutama pada pasal 3 ayat (1) disebutkan bahwa penetapan upah minimum didasarkan pada Kebutuhan Hidup Layak (KHL) dengan memperhatikan produktivitas dan pertumbuhan ekonomi. Dengan demikian, rasio UMP terhadap KHL seharusnya lebih besar dari 1 (satu). Data tahun 2000 menunjukkan bahwa semua provinsi memiliki rasio UMP terhadap KHL kurang dari 1(satu), yang kemudian pada tahun 2005 menjadi lebih baik (42,31 persen), tetapi menjadi buruk lagi pada tahun 2010 (88,46 persen).

Gini rasio merupakan salah satu indeks yang digunakan untuk melihat apakah di suatu daerah terjadi ketimpangan pendapatan antar masyarakat atau tidak. Salah satu faktor pendorong orang dari wilayah perdesaan melakukan migrasi ke wilayah perkotaan adalah karena adanya ketimpangan pendapatan, baik secara relatif (rasio pendapatan antara perkotaan dan perdesaan) maupun absolut (rata-rata pendapatan) (Sicular et al., 2007). Akan tetapi, ketimpangan pendapatan di daerah perkotaan lebih tinggi dibandingkan di daerah perdesaan karena pendapatan di daerah perkotaan bersumber dari upah pekerja dan hasil dari usaha sendiri, sedangkan pendapatan di daerah perdesaan sebagian besar bersumber dari pertanian (Hariadi $d k k$, 2008; Hoang and Yabe, 2011).

Data tahun 2007-2012 menunjukkan bahwa perkembangan indeks Gini di Indonesia secara rata-rata menunjukkan peningkatan (2,91 persen). Hal ini mengindikasikan bahwa kesenjangan antar-penduduk di Indonesia semakin lama semakin memburuk. Kondisi ini merupakan salah satu aspek yang menyebabkan orang melakukan migrasi. Ketimpangan distribusi pendapatan yang tinggi di suatu daerah akan mempercepat proses emigrasi dari daerah tersebut (Liebig dan Sousa-Poza, 2004). Indeks Gini dapat dijadikan sebagai salah satu indikator untuk melihat karakteristik pendidikan dari para migran. Wilayah dengantingkatketimpangan tinggi akan menyebabkan migran yang masuk memiliki tingkat pendidikan tinggi, sedangkan wilayah dengan tingkat gini rasio redah menyebabkan migran yang masuk adalah mereka yang memiliki tingkat pendidikan rendah (Stark, 2006).

\section{Kondisi Ketenagakerjaan}

ILO (2012) mengemukakan bahwa tingkat produktivitas tenaga kerja di Indonesia setiap tahunnya mengalami peningkatan sebesar 3,3 persen (2001-2010), tetapi masih jauh tertinggal dari negera-negara ASEAN lainnya. Sektor yang mengalami peningkatan terbesar adalah pada sektor manufaktur dan sektor jasa. Akan tetapi, jika dilihat dari aspek penyerapan tenaga kerja, sektor pertanian merupakan sektor yang memiliki tingkat penyerapan tenaga kerja terbanyak 3,51 persen per tahun (2007-2013). Dalam rentang waktu yang sama, sektor non pertanian terus mengalami peningkatan sebanyak 8,40 persen pertahun.

Table 2

Penduduk 15 Tahun ke Atas menurut Jenis Kegiatan Tahun 2011-2013

\begin{tabular}{|c|c|c|c|c|c|c|}
\hline \multirow{2}{*}{ Jenis Kegiatan } & \multicolumn{2}{|c|}{2011} & \multicolumn{2}{|c|}{2012} & \multicolumn{2}{|c|}{2013} \\
\hline & Feb & Agst & Feb & Agst & Feb & Agst \\
\hline 1. Penduduk Berumur +15 Tahun (juta) & 170.66 & 171.76 & 172.87 & 173.93 & 175.10 & 176.66 \\
\hline 2. Angkatan Kerja (juta) & 119.4 & 117.37 & 120.42 & 118.05 & 121.19 & 118.19 \\
\hline
\end{tabular}




\begin{tabular}{lcccccc}
\multirow{2}{*}{ Jenis Kegiatan } & \multicolumn{2}{c}{2011} & \multicolumn{2}{c}{2012} & \multicolumn{2}{c}{2013} \\
\cline { 2 - 7 } & Feb & Agst & Feb & Agst & Feb & Agst \\
\hline a. TPAK (\%) & 69.96 & 68.34 & 69.66 & 67.88 & 69.21 & 66.90 \\
b. Bekerja (juta) & 111.28 & 109.67 & 112.8 & 110.81 & 114.02 & 110.80 \\
c. Penganguran Terbuka (juta) $\left.{ }^{*}\right)$ & 8.12 & 7.7 & 7.61 & 7.24 & 7.17 & 7.39 \\
d. TPT (\%) & 6.80 & 6.56 & 6.32 & 6.14 & 5.92 & 6.25 \\
3. Bukan Angkatan Kerja (juta) & 51.26 & 54.39 & 52.45 & 55.87 & 53.91 & 58.47 \\
a. Sekolah (juta) & 13.94 & 13.1 & 14.31 & 14.08 & 14.97 & 14.45 \\
b. Mengurus Rumah Tangga (juta) & 30.01 & 32.89 & 31.45 & 33.63 & 32.19 & 35.23 \\
c. Lainnya (juta) & 7.31 & 8.39 & 6.69 & 8.16 & 6.75 & 8.78 \\
\hline
\end{tabular}

Pengangguran Terbuka: Mencari Pekerjaan, Mempersiapkan Usaha, Merasa Tidak Mungkin Mendapat Pekerjaan, Sudah Punya Pekerjaan tetapi belum dimulai.

Sumber: BPS, 2014

Migrasi penduduk dari daerah perdesaan ke daerah perkotaan terus mengalami peningkatan setiap tahunnya. Hasil Sensus Penduduk tahun 2010 menunjukkan bahwa para migran cenderung untuk tinggal di wilayah perkotaan dibandingkan wilayah perdesaan (Handiyatmo, 2011). Kecenderungan ini menyebabkan tenaga kerja di sektor pertanian semakin berkurang dan di sektor non-pertanian meningkat. Dengan demikian, biaya produksi untuk sektor pertanian akan semakin mahal dan akan meningkatkan harga produk pertanian. Sumanto (2009) mengemukakan bahwa migrasi tenaga kerja dari sektor pertanian ke sektor non-pertanian mulai didominasi oleh ibu rumah tangga. Hal ini disebabkan karena upah di sektor non-pertanian lebih tinggi dibandingkan dengan sektor pertanian, pendapatan keluarga yang rendah, jumlah tanggungan keluarga yang tinggi, tingkat pendidikan ibu rumah tangga yang semakin baik, dan luas lahan pertanian yang semakin sempit.

Data statistik (lihat Tabel 2) menunjukkan bahwa pertumbuhan penduduk usia 15 tahun keatas lebih kecil dibandingkan dengan pertumbuhan lapangan kerja. Hal ini dapat dilihat dari jumlah Tingkat Pengangguran Terbuka (TPT) yang setiap tahunnya mengalami penurunan sebesar 5.07 persen per-tahun (2007-2013). Kesenjangan yang semakin tinggi antara pertumbuhan penduduk dan pertumbuhan lapangan kerja akan menyebabkan masalah sosial bagi suatu wilayah. Masalah sosial yang tinggi akan berpengaruh terhadap buruknya perekonomian wilayah tersebut dan akan menurunkan pertumbuhan ekonomi (Easterly $d k k, 2006)$.

\section{Economic Attractiveness}

Aspek kesejahteraan yang merupakan faktor penarik seseorang melakukan migrasi adalah Rasio antara Upah Minimum Provinsi (UMP) dan Kebutuhan Hidup Layak (KHL), Indeks Gini, serta PDRB per-Kapita berdasarkan harga konstan tahun 2000. Penggunaan Rasio KHL/UMP digunakan untuk melihat seberapa besar UMP yang ditetapkan dapat memenuhi KHL di suatu daerah. Menurut Undang-undang No. 13 Tahun 2003 tentang ketenagakerjaan, menyebutkan bahwa UMP disusun berdasarkan pada KHL dan pertumbuhan ekonomi. Akan tetapi, berdasarkan data tahun 2000-2013 menunjukkan bahwa ada beberapa provinsi yang belum sesuai dengan ketentuan perundangan, di mana nilai KHL lebih besar dari UMP. 
Tabel 3

Nilai Rasio UMP/KHL dari Empat Provinsi Tertinggi dan Terendah Tahun 2000, 2005, 2010, 2013

\begin{tabular}{llccccc}
\hline & \multicolumn{1}{c}{ Provinsi } & $\mathbf{2 0 0 0}$ & $\mathbf{2 0 0 5}$ & $\mathbf{2 0 1 0}$ & $\mathbf{2 0 1 3}$ & Rata-rata \\
\hline Tertinggi & Sumatera Utara & 0.80 & 1.10 & 1.05 & 1.06 & 1.00 \\
& Sulawesi Utara & 0.62 & 1.15 & 1.02 & 1.20 & 1.00 \\
& Kalimantan Selatan & 0.71 & 1.06 & 1.03 & 1.09 & 0.97 \\
& Lampung & 0.73 & 1.02 & 0.89 & 1.08 & 0.93 \\
\hline Terendah & Papua & 0.68 & 0.91 & 0.73 & 0.83 & 0.79 \\
& Bali & 0.67 & 1.00 & 0.86 & 0.56 & 0.77 \\
& Maluku & 0.80 & 0.83 & 0.60 & 0.73 & 0.74 \\
& Nusa Tenggara Barat & 0.56 & 0.90 & 0.61 & 0.78 & 0.72 \\
\hline
\end{tabular}

Sumber: BPS, 2014 dan Pusdatinaker, 2014 (diolah).

Indeks Gini merupakan suatu indikator yang digunakan untuk mengukur kesenjangan pendapatan dan kekayaan antar penduduk di suatu wilayah (Gastwirth et al., 2005). Nilai Indeks Gini berkisar antar 0 dan 1 , di mana nilai yang mendekati nilai 0 maka dapat dikatakan bahwa pemerataan pendapatan dan kekayaan antar-penduduk semakin sempurna, dan sebaliknya. Data

Tabel 4

Indeks Gini dari Empat Provinsi Tertinggi dan Terendah Tahun 1999, 2005, 2010, 2013

\begin{tabular}{llrrrrl}
\hline & \multicolumn{1}{c}{ Provinsi } & $\mathbf{1 9 9 9}$ & $\mathbf{2 0 0 5}$ & $\mathbf{2 0 1 0}$ & $\mathbf{2 0 1 3}$ & Rata-rata \\
\hline Tertinggi & DI Yogyakarta & 0.337 & 0.415 & 0.410 & 0.439 & 0.400 \\
& Papua & 0.360 & 0.389 & 0.410 & 0.442 & 0.400 \\
& Sulawesi Tenggara & 0.276 & 0.364 & 0.420 & 0.426 & 0.372 \\
& Sulawesi Selatan & 0.296 & 0.353 & 0.400 & 0.429 & 0.370 \\
\hline Terendah & Riau & 0.224 & 0.283 & 0.330 & 0.374 & 0.303 \\
& Jambi & 0.240 & 0.311 & 0.300 & 0.348 & 0.300 \\
& Maluku & 0.241 & 0.258 & 0.330 & 0.370 & 0.300 \\
& Kalimantan Tengah & 0.237 & 0.283 & 0.300 & 0.350 & 0.293 \\
\hline
\end{tabular}

Sumber: BPS, 2014.

Salah satu ukuran kesejahteraan yang dapat dibandingkan antara satu wilayah dengan wilayah lainnya adalah PDRB per kapita. Data menunjukkan bahwa provinsi yang memiliki rata-rata PDRB per kapita tertinggi adalah DKI Jakarta dan yang terendah adalah provinsi Nusa Tenggara Timur. Jika dikaitkan dengan kepemilikan
Indeks Gini menunjukkan bahwa tingkat pemerataan pendapatan dan kekayaan antar penduduk pada masing-masing provinsi di Indonesia berada dalam kategori menengah dan rendah. Hal ini berarti hanya sebagian kecil masyarakat yang memiliki pendapatan dan kekayaan yang lebih tinggi dari masyarakat lainnya di suatu provinsi. sumber daya alam, maka provinsi yang melimpah sumber daya alam (contoh: Kalimantan Timur, Riau, dan Papua) cenderung memiliki PDRB per kapita yang tinggi dibandingkan dengan provinsi yang kurang sumber daya alam (contoh: Nusa Tenggara Barat, Maluku, dan Nusa Tenggara Timur). 
Tabel 5

PDRB per kapita berdasarkan harga konstan tahun 2000 dari Empat Provinsi Tertinggi dan Terendah Tahun 2000, 2005, 2010 (juta)

\begin{tabular}{llllll}
\hline & \multicolumn{1}{c}{ Provinsi } & $\mathbf{2 0 0 0}$ & $\mathbf{2 0 0 5}$ & $\mathbf{2 0 1 0}$ & Rata-rata \\
\hline Teritinggi & DKI Jakarta & 27.97 & 33.32 & 41.18 & 34.16 \\
& Kalimantan Timur & 30.22 & 32.97 & 31.23 & 31.47 \\
& Riau & 12.50 & 17.31 & 17.65 & 15.82 \\
& Papua & 8.57 & 11.84 & 7.91 & 9.44 \\
\hline Terendah & Bengkulu & 3.13 & 4.03 & 4.86 & 4.01 \\
& Nusa Tenggara Barat & 3.02 & 3.63 & 4.46 & 3.70 \\
& Maluku & 2.35 & 2.60 & 2.77 & 2.57 \\
& Nusa Tenggara Timur & 1.94 & 2.32 & 2.68 & 2.31 \\
\hline
\end{tabular}

Sumber: BPS, 2014 (diolah).

Ketiga aspek kesejahteraan diatas merupakan faktor penarik bagi penduduk untuk melakukan migrasi dari satu daerah ke daerah yang lainnya. Hasilanalisis menunjukkan bahwa nilai economic attractiveness dari variabel Rasio UMP/KHL dan PDRB per kapita adalah positif dan signifikan $(0,2501$ dan 0,2742, secara berturut-turut). Sedangkan untuk nilai indeks gini memiliki tanda negatif 0,0730, tetapi tidak signifikan. Hal ini disebabkan oleh perbedaan indeks gini antara satu wilayah dengan wilayah lainnya yang tidak jauh berbeda atau homogen (dapat dilihat dari nilai standar deviasi). Kondisi ini menyebabkan nilai economic attractiveness dari indeks gini tidak diikutsertakan dalam perhitungan.

Tabel 6

Nilai Economic Attractiveness (EA)

\begin{tabular}{|c|c|c|c|c|c|}
\hline Keterangan & & 2000 & 2005 & 2010 & EA \\
\hline \multirow[t]{4}{*}{ Rasio UMP/KHL } & Tertinggi & 0.8046 & 1.1489 & 1.0534 & $0.2501^{* *}$ \\
\hline & Terendah & 0.5639 & 0.8293 & 0.5996 & $(0.1078)$ \\
\hline & Rata-rata & 0.6665 & 0.9871 & 0.8857 & \\
\hline & Standar Deviasi & 0.0669 & 0.0795 & 0.1241 & \\
\hline \multirow[t]{4}{*}{ Indeks Gini } & Tertinggi & 0.3600 & 0.4150 & 0.4200 & -0.0730 \\
\hline & Terendah & 0.2240 & 0.2580 & 0.3000 & $(0.0971)$ \\
\hline & Rata-rata & 0.2740 & 0.3249 & 0.3620 & \\
\hline & Standar Deviasi & 0.0305 & 0.0382 & 0.0316 & \\
\hline \multirow[t]{4}{*}{ PDRB per kapita (juta) } & Tertinggi & 30.2234 & 33.3249 & 41.1772 & $0.2742^{* * *}$ \\
\hline & Terendah & 1.9357 & 2.3160 & 2.6788 & $(0.1017)$ \\
\hline & Rata-rata & 6.8944 & 8.2822 & 9.4118 & \\
\hline & Standar Deviasi & 7.0251 & 8.0675 & 8.6642 & \\
\hline
\end{tabular}

Ket: * signifikan pada level signifikasi $10 \%$,

** signifikan pada level signifikasi $5 \%$,

*** signifikan pada level signifikasi $1 \%$

Sumber: Data Olahan, 2014

\section{Kecederungan Migrasi}

Peluang seseorang melakukan migrasi didasari oleh dua faktor, yaitu tujuan dari migrasi (ekonomi dan non-ekonomi) dan penyebab untuk melakukan migrasi (faktor penarik, faktor pendorong, dan lainnya/ contoh: jaringan) (Martin dan Zurcher, 2008). Berbagai riset menujukkan bahwa faktor daya tarik ekonomi menyebabkan peluang orang melakukan migrasi lebih besar dibandingkan 
dengan faktor non-ekonomi, baik di negara berkembang maupun negara maju (OECD, 2004; Hugo, 2006). Selain faktor ekonomi, faktor non-ekonomi (seperti aspek geografi (jarak)) juga mempengaruhi keputusan sese- orang melakukan migrasi. Migrasi di dalam negara itu sendiri merupakan migrasi yang paling banyak dilakukan kemudian diikuti oleh migrasi antar-negara yang bersebelahan (Molloy et al., 2011).

Tabel 7

Kecenderungan Migrasi dari Provinsi di Indonesia (per 100.000 penduduk) berdasarkan Provinsi Tujuan dari Migran

\begin{tabular}{|c|c|c|c|}
\hline Peringkat & Provinsi Tujuan & Total & Provinsi Asal \\
\hline 1. & Jawa Barat & $2,255.31$ & $\begin{array}{l}\text { Sumatera Utara, DKI Jakarta, Jawa Tengah, } \\
\text { Kalimantan Tengah }\end{array}$ \\
\hline 2. & Riau & $1,032.83$ & Sumatera Utara, Sumatera Barat \\
\hline 3. & Kalimantan Timur & 804.96 & $\begin{array}{l}\text { Bali, Kalimantan Tengah, Kalimantan Selatan, } \\
\text { Sulawesi Utara, Sulawesi Tengah, Sulawesi Selatan }\end{array}$ \\
\hline 4. & DKI Jakarta & 700.97 & Lampung, Jawa Tengah, Bali, Kalimantan Barat \\
\hline 5. & Papua & 628.70 & $\begin{array}{l}\text { Sumatera Barat, Sulawesi Utara, Sulawesi Tenggara, } \\
\text { Maluku }\end{array}$ \\
\hline 6. & Yogyakarta & 536.92 & $\begin{array}{l}\text { Jambi, Sumatera Selatan, Bengkulu, Jawa Barat, Jawa } \\
\text { Timur, NTB, NTT, Kalimantan Timur, Sulawesi } \\
\text { Tengah, Sulawesi Tenggara }\end{array}$ \\
\hline 7. & Sumatera Barat & 257.69 & Jambi, Bengkulu, DKI Jakarta \\
\hline 8. & Sulawesi Tengah & 251.59 & Sulawesi Selatan \\
\hline 9. & Sulawesi Tenggara & 229.06 & Riau, Maluku \\
\hline 10. & Bali & 228.84 & Riau, NTB, NTT, Kalimantan Timur \\
\hline 11. & Jambi & 87.53 & Lampung, Kalimantan Selatan \\
\hline 12. & Sumatera Utara & 85.97 & Papua \\
\hline 13. & Bengkulu & 78.48 & Sumatera Selatan \\
\hline 14. & Lampung & 37.17 & Jawa Timur \\
\hline 15. & Sumatera Selatan & 36.48 & Papua \\
\hline 16. & Jawa Timur & 36.24 & Kalimantan Barat \\
\hline 17. & Sulawesi Selatan & 6.24 & Jawa Barat \\
\hline
\end{tabular}

Sumber: Data Olahan, 2014

Hasil analisis menunjukkan bahwa aspek jarak dan aspek economic attractiveness (Rasio UMP/KHL dan PDRB per kapita) merupakan faktor yang menyebabkan migrasi antar provinsi di Indonesia. Kecenderungan migrasi antar provinsi di Indonesia memperlihatkan bahwa pulau Jawa (Jawa Barat, Yogyakarta, Jawa Timur, dan DKI Jakarta) dan pulau Bali merupakan tujuan utama migrasi. Hasil studi ini sejalan dengan hasil Sensus Penduduk tahun 2010, di mana Provinsi Jawa Barat merupakan provinsi penerima migran terbesar. Selain itu, migrasi penduduk yang berada dalam satu pulau (migration within island) merupakan alternatif migrasi yang dilakukan oleh penduduk.
Pola pengatupan (polarisasi) dari migrasi antar-provinsi di Indonesia menyebabkan ketidakseimbangan sumber daya manusia antar provinsi di Indonesia, di mana ada provinsi yang berlimpah dan ada yang kekurangan sumber daya manusia. Jika kondisi ini terus berlangsung, maka ketimpangan pembangunan antar provinsi di Indonesia tetap akan terjadi, di mana provinsi-provinsi yang ada pulau Jawa dan Bali akan cenderung maju dibandingkan dengan provinsi-provinsi lainnya di luar pulau Jawa dan Bali.

Hasil studi ini juga menunjukkan bahwa Provinsi DI Yogyakarta merupakan satu-satunya provinsi di Indonesia yang 
penduduknya tidak memiliki kecenderungan melakukan migrasi, baik migrasi antar pulau maupun migrasi dalam satu pulau. Dalam kurun waktu 10 tahun (2000-2010), pertumbuhan penduduk Provinsi DI Yogyakarta termasuk dalam 10 provinsi yang memiliki pertumbuhan terendah (10.74 persen). Akan tetapi, perlu penelitian lebih lanjut terkait dengan faktor-faktor yang mempengaruhi rendahnya kecenderungan penduduk di Provinsi DI Yogyakarta untuk melakukan migrasi.

\section{SIMPULAN}

Hasil analisis menunjukkan bahwa variabel Rasio UMP/KHL dan PDRB per kapita memiliki dampak positif dan signifikan (secara berturut-turut 0,2501 dan 0,2742). Sedangkan variabel Indeks Gini memiliki dampak negatif, tetapi tidak signifikan $(-0,0730)$. Jika dibandingkan dengan penelitian sebelumnya yang dilakukan oleh Darmawan dan Chotib (2007), maka indikator PDRB per kapita memiliki arah dan signifikansi yang sama. Indikator UMP pada penelitian sebelumnya memiliki arah yang negatif dan tidak signifikan. Hal ini diduga disebabkan oleh data UMP sebelum krisis relatif stabil dan tidak banyak mengalami perubahan dibandingkan dengan data UMP setelah krisis. Penelitian ini menggunakan rasio UMP/KHL dengan dasar bahwa dalam memilih lokasi migrasi, para migran akan memperhitungan keuntungan (UMP) dan biaya (KHL) yang akan diperoleh.

Kecenderungan migrasi penduduk di Indonesia dibagi dalam dua tipe yaitu: migrasi antar-pulau dan migrasi dalam pulau. Tujuan utama migrasi antar pulau masih didominasi oleh Pulau Jawa (Yogyakarta, Jawa Barat, Jawa Timur, dan DKI Jakarta) dan Bali. Sedangkan migrasi di dalam pulau lebih disebabkan oleh jarak dan kedekatan budaya antar provinsi dalam satu pulau. Hal ini menunjukkan bahwa Pulau Jawa masih merupakan daerah tujuan utama dari para migran. Hal ini mengindikasikan bahwa pemerataan pembangunan antar- provinsi di Indonesia belum baik. Dengan demikian, sangat penting untuk melakukan percepatan terhadap program-program dalam Masterplan Percepatan dan Perluasan Pembangunan Ekonomi Indonesia (MP3EI).

Selain itu, hasil penelitian juga menunjukkan bahwa masyarakat di Provinsi DI Yogyakarta memiliki kecenderungan untuk tidak melakukan migrasi, di mana dalam penelitian ini tidak diteliti secara mendalam. Dengan demikian, perlu untuk melakukan penelitian mendalam terkait dengan faktor yang mempengaruhi kecenderungan tersebut.

\section{DAFTAR PUSTAKA}

Adams, Jr. R.H dan J. Page. 2005. “Do International Migration and Remittances Reduce Poverty in Developing Countries?". World Development, 33 (10): 1645-1669.

Adema, W dan M. Ladaique. 2009. How Expensive is the Welfare State? Gross and Net Indicators in the OECD Social Expenditure Database (SOCX). OECD Social, Employment and Migration Working Paper No. 92.

Badan Pusat Statistik (BPS). 2014. Data Migrasi, Ketenagakerjaan, Upah Minimum Provinsi, Gini Indeks, dan PDRB per kapita. http://www.bps.go.id. 23 Juli 2014 (08:45).

BNP2TKI, 2013. Data Penempatan Tenaga Kerja Indonesia (TKI). Badan Nasional Penempatan dan Perlindungan Tenaga Kerja Indonesia, Jakarta.

Darmawan, B dan Chotib. 2007. Perkiraan Pola Migrasi Antarprovinsi di Indonesia Berdasarkan "Indeks Ketertarikan Ekonomi". Pararel Session IIIC: Poverty, Population and Health, Wisma Makara, Kampus UI-Depok, 13 Desember.

Deshingkar, P. 2006. Internal Migration, Poverty and Development in Asia: Including the Excluded through Partnerships and Improved Governance. Dipresentasikan di International Conference "Asia 2015: Ending Poverty?", Manila, 18-20 October 2006. 
Devlin, C., O. Bolt, D. Patel, D. Harding dan I. Hussain. 2014. Impacts of Migration on UK Native Employment: An Analytical Review of the Evidence. Department for Bussiness Innovation and Skills, Occasional Paper 109. United Kingdom.

Easterly, W., J. Ritzen, dan M. Woolcock. 2006. "Social Cohesion, Institutions, and Growth". Economics and Politics, 18(2): 103-120.

Gastwirth, J., Modarres, R., dan Bura, E. 2005. "The Use of the Lorenz Curve, Gini Index and Related Measures of Relative Inequality and Uniformity in Securities Law". International Journal of Statistics, 63(3): 451-469.

Giulietti, C. 2014. "Is the Minimum Wage a Pull Factor for Immigrants?". Industrial and Labor Relations Review, 67: 649-674.

Giulietti, C., M. Guzi, M. Kahanec, dan K.F. Zimmermann.2013.“Unemployment Benefits and Immigration: Evidence from the EU". International Journal of Manpower, 34(1): 24-38.

Handiyatmo, D. 2011. Migrasi Internal Penduduk Indonesia: Hasil Sensus Penduduk 2010. Subdirektorat Statistik Demografi, Badan Pusat Statistik, Jakarta.

Hariadi, P., Arintoko, dan Bawono, I.R. 2008. "Ketimpangan Distribusi Pendapatan di Kabupaten Bayumas Jawa Barat". Jurnal Ekonomi Pembangunan, 13(2): 61-70.

Heitmueller, A. 2005. “Unemployment Benefit, Risk Aversion, and Migration Incentives". Journal of Pupulation Economics, 18(1): 93-112.

Hugo, G. 2006. "Forced Migration in Indonesia: Historical Perspectives". Asian and Pacific Migration Journal, 15(1): 53-92.

Hoang, L.V and M. Yabe. 2011. “The Change of Income Inequality Dimensions in Rural Vietnam: A Perspective From
Agriculture Production". China-USA Business Review, 10(12): 1347-1360.

ILO. 2012. Profil Pekerjaan yang Layak: Indoensia. International Labor Organization. Indonesia.

Isserman, A.M., D.A. Plane, P.A. Rogerson, dan P.M. Beaumont. 1985. "Forecasting Interstate Migration with Limited Data: A DemographicEconomic Approach". Journal of the American Statistical Association, 80(390): 277-285.

Kerr, S.P dan Kerr, W.R. 2011. "Economic Impacts of Immigration: A Survey". Finnish Economic Paper, 24(1):1-32.

Liebig, T dan A. Sousa-Poza. 2004. "Migration, Self-Selection and Income Inequality: An International Analysis". KYKLOS, 57(1): 125-146.

Lu, Y. 2010. "Rural-Urban Migration and Health: Evidence from Longitudinal Data in Indonesia". Social Science and Medicine, 70(3): 412-419.

Lumpe, C. 2007. The Labor Market Impact of Immigration: Theory and Evidence. Discursion Paper, No. 3468269275, Centre for European Economic Research, Germany.

Martin, P dan G. Zurcher. 2008. “Managing Migration: The Global Challenge". Population Bulletin, 63(1): 1-20.

Mayda, A.M. 2010. “International Migration: A Panel Data Analysis of the Determinants Bilateral Flows". Journal of Population Economics, 23(4): 1249-1274.

Molloy, R., Smith, C.L. dan Wozniak, A. 2011. "Internal Migration in the United States". Journal of Economic Perspectives, 25(3): 173-196.

OECD. 2004. Trends in International Migration, Part II: Regional Asepct of Migration. OECD Publishing.

Primawati, A. 2011. "Remitan Sebagai Dampak Migrasi Pekerja ke Malaysia". Jurnal Sosiokonsepsia, 16 (2): 209-221. 
Purnomo, D. 2009. “Fenomena Migrasi Tenaga Kerja dan Perannya Bagi Pembangunan Daerah Asal: Studi Empiris di Kabupaten Wonogiri". Jurnal Ekonomi Pembangunan, 10(1): 84-102.

Saptanto, S., Lindawati, dan Zulham, A. 2011. "Analsisi Pola Migrasi dan Konsumsi Rumah Tangga di Daerah Asal Migrasi terkait Kemiskinan dan Kerentanan Pangan (Studi Kasus Indramayu)". Jurnal Organisasi dan Manajemen, 7(1): 21-37.

Sicular, T., Y. Ximing, B. Gustafsson, dan L. Shi. 2007. "The Urban-Rural Income Gap and Inequality in China". Review of Income and Wealth, 53(1): 93-126.

Stark, O. 2006. "Inequality and Migration: A Behavioral Link". Economics Letters, 91(1): 146-152.

Sumanto, A. 2009. Identifikasi Faktor-faktor Sosial-Ekonomi Migrasi Tenaga Kerja (Kasus Ibu Rumah Tangga yang Bekerja dari Sektor Pertanian ke Sektor Non Pertanian). Jurnal Ekonomi dan Studi Pembangunan (JESP), 1(2): 74-80.
Tirtosudarmo, R. 2009. Mobility and Human Development in Indonesia. Human Development Research Paper 2009/19. United Nations Development Programme.

The Word Bank. 2009. Word Development Report 2009: Reshaping Economic Geography. The International Bank for Reconstruction and Development/ The World Bank. Washington DC.

Vujicic, M., P. Zurn, K. Diallo, O. Adams and M.R.D. Poz. 2004. "The Role of Wages in the Migration of Health Care Professionals from Developing Countries". Human Resources for Health, 2(3): 1-14.

Wajdi, M.N. 2010. Migrasi Antarpulau di Indonesia: Analisis Model Skedul Migrasi dan Model Gravitasi Hybrida. Tesis. Kajian Kependudukan dan Ketenagakerjaan Program Pascasarjana Universitas Indonesia. Jakarta.

Wahyuni, S dan Nuraini. 2013. Estimasi Parameter Demografi: Tren Fertilitas, Mortalitas, dan Migrasi (Hasil Sensus Penduduk 2010). Badan Pusat Statistik, Jakarta. 